\title{
Insights on bovine genetic engineering and cloning ${ }^{1}$
}

\author{
Fabiana F. Bressan ${ }^{2 *}$, Juliano R. Sangalli ${ }^{2,3}$, Laís V.F. Pessôa ${ }^{2,3}$, Pedro R.L. Pires ${ }^{2,3}$ \\ and Flávio V. Meirelles ${ }^{2}$
}

\begin{abstract}
Bressan F.F, Sangalli J.R., Pessôa L.V.F., Pires P.R.L. \& Meirelles F.V. 2013. Insights on bovine genetic engineering and cloning. Pesquisa Veterinária Brasileira 33(Supl.1):113118. Departamento de Medicina Veterinária, Faculdade de Zootecnia e Engenharia de Alimentos, Universidade de São Paulo, Av. Duque de Caxias Norte 225, Pirassununga, SP 13635900, Brazil. E-mail: fabianabressan@usp.br

Transgenic technology has become an essential tool for the development of animal biotechnologies, and animal cloning through somatic cell nuclear transfer (SCNT) enabled the generation of genetically modified animals utilizing previously modified and selected cell lineages as nuclei donors, assuring therefore the generation of homogeneous herds expressing the desired modification. The present study aimed to discuss the use of SCNT as an important methodology for the production of transgenic herds, and also some recent insights on genetic modification of nuclei donors and possible effects of gene induction of pluripotency on SCNT.
\end{abstract}

INDEX TERMS: Induced pluripotency, transgenic technology, somatic cell nuclear transfer, cattle.

RESUMO.- [Experiências em clonagem e transgenia em bovinos.] Tecnologias de modificação genética têm se tornado ferramentas essenciais para o desenvolvimento de biotecnologias animais. A clonagem animal mediante transferência nuclear de célula somática (TNCS) possibilitou a geração de animais geneticamente modificados através da utilização de linhagens celulares previamente modificadas e selecionadas como doadoras de núcleo, garantindo desta maneira a geração de rebanhos homogênoes expressando a modificação desejada. 0 presente estudo objetivou discutir o uso da TNCS como importante metodologia para a produção de rebanhos transgênicos, assim como experiências recentes na manipulação genética de células doadoras de núcleo e possíveis efeitos da indução gênica à pluripotência na TNCS.

TERMOS DE INDEXAÇÃO: Pluripotência induzida, tecnologia transgênica, transferência nuclear de célula somática, bovino.

\footnotetext{
${ }^{1}$ Received on July 17, 2013.

Accepted for publication on December 9, 2013.

${ }^{2}$ Departamento de Medicina Veterinária, Faculdade de Zootecnia e Engenharia de Alimentos (FZEA), Universidade de São Paulo (USP), Av. Duque de Caxias Norte 225, Pirassununga, SP 13635-900, Brazil. *Corresponding author: fabianabressan@usp.br

${ }^{3}$ Departamento de Cirurgia, Faculdade de Medicina Veterinária e Zootecnia (FMVZ), USP, Av. Prof. Dr. Orlando Marques de Paiva 87, São Paulo, SP 05508-270, Brazil.
}

\section{INTRODUCTION}

The technology of genetic engineering plays an important role on both basic and applied research, becoming an essential tool for the understanding of the biology and development of animal biotechnology. Such technology presents a wide range of applications, such as the production of biopharmaceuticals, studies on gene expression and its regulation, the improvement of animal production, as, for example, production of herds resistant to specific diseases, and many other biomedical and medical purposes (Jaenisch et al. 1988, Houdebine 2005).

Over the last decades several techniques were developed in order to produce genetically modified animals, and three of them became more popular due to their simplicity and positive results: exogenous pronuclear DNA microinjection in zygotes, injection of genetically modified embryonic stem (ES) cells into blastocysts, and, more recently, retrovirus mediated gene transfer (Gordon \& Ruddle 1981, Hammer et al. 1985, Gossler et al. 1986, Hofmann et al. 2003, 2004). Injection of ES cells into blastocysts is the most popular methodology of genetic manipulation in mice, once homologous recombination of ES cells in mice is feasible, allowing the contribution of modified cells in the embryos and therefore obtaining transgenic animals after breeding (Misra \& Duncan 2002).

ES cells, however, have not yet been fully characterized in domestic or wild animals (Prelle et al. 2002, Keefer et 
al. 2007), hindering its use on the production of transgenic herds.

As an alternative to the non-feasibility of ES injection in blastocysts, as well as to the low rates of births of transgenic animals after microinjection, the SCNT, most commonly known as cloning, has become a promising alternative to the generation of genetically modified animals, once enabling the use of somatic cells previously modified as genetic material donors. The association of SCNT with an efficient genetic engineering of donor cells allows, besides several other advantages, guarantees the production of modified animals without the occurrence of mosaicism when compared to other techniques such as pronuclear microinjection. In other words, $100 \%$ of born animals will harbor the desired modification (revised by Park 2007).

In the search of a higher SCNT efficiency, resulting not only in the increase on the number of produced cloned embryos in vitro, but mostly in the increase of the healthy animals born, recent strategies comprising the selection of cell lineages most prone to cell reprogramming must be investigated. The present manuscript aimed to show cloning as an important tool in the production of transgenic herds, to discuss some recent results from our group regarding genetic modification of nuclei donor cells, and also to propose a possible beneficial effect of genetic induced reprogramming on SCNT.

\section{SOMATIC CELL NUCLEAR TRANSFER AS THE METHOD OF CHOICE FOR THE PRODUCTION OF GENETICALLY MODIFIED ANIMALS}

SCNT comprises the removal of genetic material of an oocyte and its replacement with a donor cell nucleus derived from the animal to be cloned. More than 15 years have passed since the birth of the sheep Dolly, the first mammal cloned from the cells of an adult animal, however cloning is still an inefficient process. Of all cloned embryos transferred into recipient cows, usually less than 5\% may develop in a healthy animal (Wilmut 2002, Cibelli et al. 2007, Meirelles et al. 2010).

Although SCNT efficiency is still low, it is the technique that presents greater transgene expression stability in modified animals. The use of genetically modified nuclei donors has been accentuated within the technologies used for the production of such animals, once it assures the develo- pment on animal known already to be transgenic without the need of waiting until birth to check the presence and expression of the desired gene, as well as the exogenous gene integration position in the host genome (Bressan et al. 2011, Monzani et al. 2013).

Transgenic cattle are not a novelty, and models of bioreactors producing recombinant proteins, or disease-resistant animals, for example, resistant to bovine spongiform encephalopathy, have already been generated (Wongsrikeao et al. 2011). Also, the generation of several models for study has already gained its field; an example is the generation of cloned transgenic cattle for the study of the fetal-maternal interaction in cloned pregnancies (Pereira et al. 2013).

Recently, Monzani et al. $(2011,2013)$ reported the production of epithelial cell lineages derived from mammary gland expressing the recombinant human coagulation Factor IX (rFIX). The rFIX is an example of recombinant protein of biomedical interest which large-scale production would greatly benefit from bioreactor animals, once its expression and purification from in vitro cell cultures is expensive, and large-scale production is limited.

In the studies mentioned above, the lentiviral system was associated with SCNT for the production of modified animals. Lentiviral vectors harboring rFIX driven by bovine $\beta$-casein promoter were transduced, cells were selected via antibiotic resistance, seeded in extracellular matrix, hormonally induced to evaluate promoter efficacy and used as donor cells for SCNT. Transgenic embryo production was $28.4 \%$ (percentage of embryos that developed into blastocysts after 7 days of in vitro culture), similar to results found in our lab for the production of non-transgenic cloned embryos (data not shown). These embryos were transferred to recipient cows $(n=21)$ and 2 animals developed into term, however, were able to survive only for a few hours in extra-uterine period despite intensive neonatal care (Fig.1).

Another study recently conducted reported that the identification of the transgene insertion site on nuclei donors cells prior to cloning may avoid the production of animals harboring undesirable characteristics due to possible positional effects, and more than that, may assure the presence of the transgene construction, and its expression, in the offspring (Bressan et al. 2011).
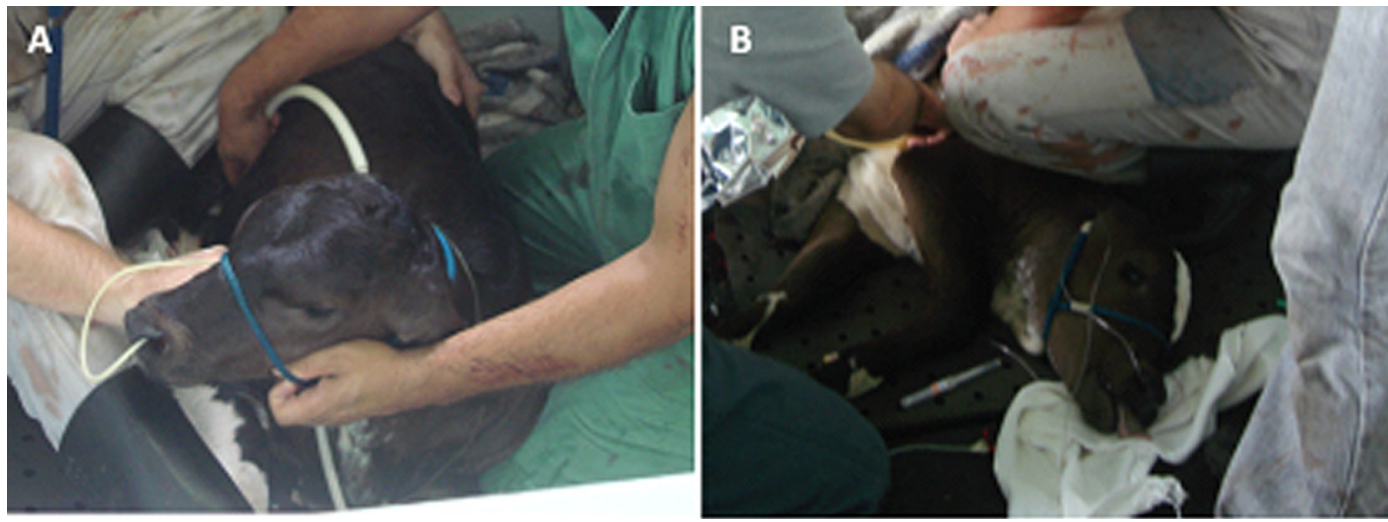

Fig.1. (A,B) Newborn cloned animals 1 and 2, respectively, receiving intensive neonatal care. 
In the study mentioned above, when embryo development and establishment and maintenance of initial pregnancies were compared between embryos reconstructed with transgenic fibroblasts presenting random transgene insertion into the genome of cells (random insertion group) or known insertion sites (recloned group), the latter showed a higher embryo production (14.42 vs. $25.38 \%$ ) and percentage of 30 days pregnancies ( 2.56 vs. $14.29 \%$, respectively). Further, the recloned group presented a more homogenous transgene (eGFP) expression within the fetuses produced, leading to the conclusion that the use of cell lineages previously characterized regarding transgene expression and integration allows the generation of animals presenting stable and homogenous transgene expression, improving the production of transgenic herds.

Undoubtedly an important tool for transgenic technologies, SCNT also benefits from transgenesis, composing what may be informally called a "two-way highway". Pereira and collaborators reported the use of a bovine cloned transgenic model expressing eGFP on the investigation of the mechanisms of fetal-maternal cellular interactions on bovine placenta (Figure 2, Pereira et al. 2013). Analysis of the presence and expression of the eGFP gene showed that the fetal DNA was found in the circulating blood of recipient cows at $47 \mathrm{~d}$ of pregnancy. Moreover, fetal protein and mRNA were analyzed by PCR, western blotting e immunohistochemistry and found in trophoblast and uterine tissues. The mecha- nisms involved in fetal molecules transfer to the maternal system are yet not fully unraveled; hence, the proposed model should be fundamental to innumerous future studies.

\section{CLONING WITH PRE-REPROGRAMMED CELLS: INDUCTION INTO PLURIPOTENCY IN CATTLE}

Innumerous features may contribute to unstable results when producing cloned animals, and the selection of cell lineage as nuclei donor has been considered crucial to obtain success in such production. Apparently, flaws on epigenetic reprogramming of nuclei donors are the main cause of the low efficiency (Dean et al. 2001).

Evidences show that the use of undifferentiated cells for cloning may result in higher SCNT efficiency (Hiiragi et al., 2005) probably because its nucleus is in a more "reprogrammable" status. As mentioned before, the use of ES cells as nuclei donors leads to higher developmental rates, similar to those obtained in in vitro fertilized animals. Conversely, the use of cells derived from adult animals leads to low developmental rates.

Even though when donor cells derived from animals with the same age are used, differences exist on their ability to guide and maintain the development of the organism until term, probably in consequence of different properties or characteristics between cytoplasm, genome or epigenome. Specific properties, molecules or mechanisms influencing such "cellular reprogramability" (cell ability to be re-
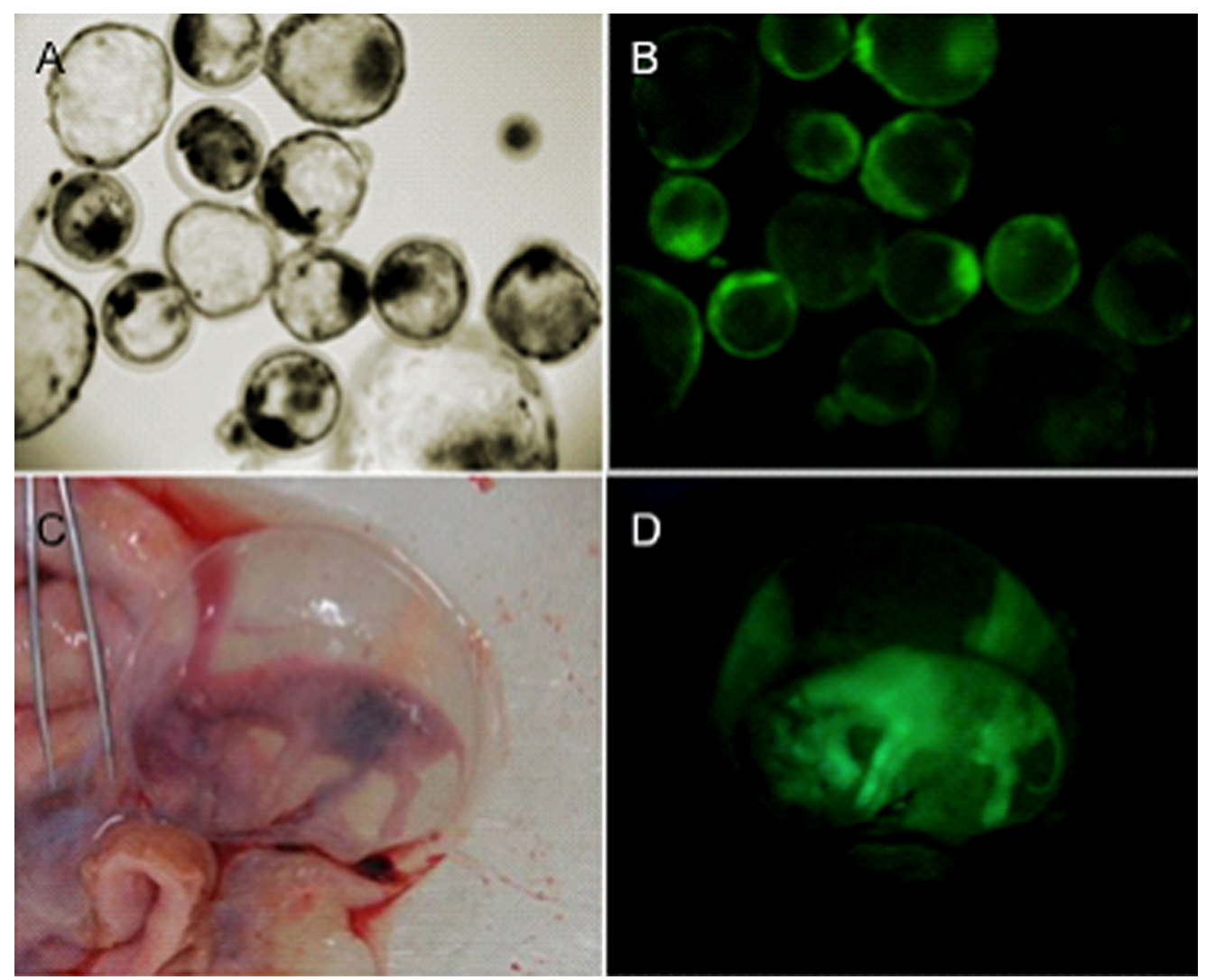

Fig.2. Embryos on $7^{\text {th }}$ day of in vitro culture. (A) Cloned embryos exposed to white light. (B) Cloned embryos exposed to fluorescence. 100x. (C,D) eGFP fluorescent bovine fetuses at 60 days of pregnancy inside amniotic membrane after hysterectomy. Bright field and fluorescence, respectively. (Figure adapted from Bressan et al. 2011). 
programmed by the oocyte cytoplasm) are not yet totally understood.

The selection and reprogramming of cell lineages prior to the process of nuclear transfer may benefit the outcomes of SCNT. However, bovine cells derived from the inner cell mass of blastocysts are not able to maintain pluripotent characteristics when cultured in vitro, therefore its use in nuclear transfer procedures aiming large-scale cloned animal production, is still unavailable.

An elegant alternative regarding the use of undifferentiated cells is the recent generation of induced pluripotent stem cells (induced pluripotent stem cells, iPS), which became a major tool on the manipulation of cellular reprogramming in vitro. Whereas ES cells are not characterized/ maintained in vitro in farm animals, iPS cells (which are differentiated cells induced to pluripotency with the forced expression of some pluripotency transcription factors, most commonly Oct4, Klf4, Sox 2 and c-Myc-OKSM), showed great similarity regarding self-renewing and ability to differentiate into tissues from the three germ layers. Hence, iPS cells are able to maintain the gene expression and typical morphology related to pluripotency even after a long period of in vitro culture (Esteban et al. 2009, Nagy et al. 2011, Sumer et al. 2011).

Recent data from our research group have shown that cells from farm animals may be reprogrammed to pluripotency after lentiviral transduction of interspecific factors (OKSM), and reprogrammed cells presented several pluripotency markers, being characterized in a pluripotent status not yet seem in stem-cells like from farm animals (Fig.3). Bovine fetal fibroblasts, as well as mesenchymal prior to SCNT is now possible. iPS cells may be genetically modified in vitro and submitted to cloning, resulting therefore in transgenic embryos, as shown in Figure 4, where bovine iPS were transduced with the eGFP reporter gene, selected and recovered by flow citometry and sorting and subsequently used as nuclei donors for SCNT.

Moreover, in the murine model pluripotent cells are known to be more permissive to homologous recombination, enabling the generation of transgenic animals through germ line contribution of the modified cells in the pre-implantation embryo; without, therefore, the use of SCNT and its disadvantages, e.g., low developmental rates. Although highly desirable, and even with the advent of iPS cells in domestic animals, such model is still unsuitable for the production of transgenic cattle because it results in mosaicism in the first generation, and animal truly transgenic may be only produced after one or more generations, an undesirable feature for the production of animals with long periods of generation intervals.

\section{CONCLUSIONS AND PERSPECTIVES}

The ability to manipulate live organisms genetically through insertion or silencing of specific genes have revolutionized the understanding of cellular and molecular biology and opened new perspectives on human and veterinary medicine.

Since the cloning of the first mammal was reported, innumerous new applications of SCNT were assembled, in which the production autologous embryonic stem cell and the generation of transgenic animals are certainly the most interesting ones. The first has become unsuitable mostly due to ethical and religious questions. The latter, however, is the

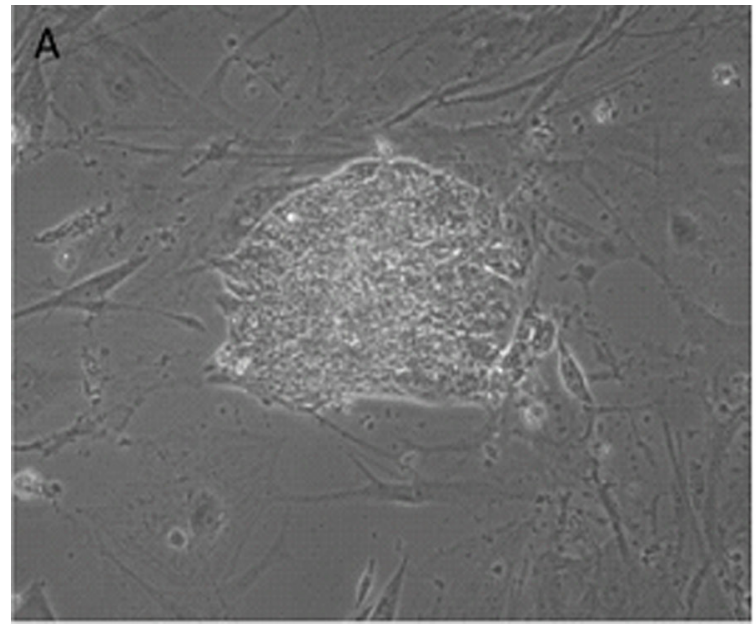

Fig.3. (A) Equine iPS. 200x. (B) Bovine iPS. 200x.

equine cells were induced to pluripotency with interspecific OKSM. Bovine iPS and fibroblasts were used as nuclei donors in SCNT resulting in cloned embryos in both groups, however, the procedure still needs further studies on cell cycle synchronization (unpublished data).

Besides the possible use of cellular reprogramming for increasing SCNT rates, it is important to highlight that genetic modifications performed in these in vitro reprogrammed cells, followed by its in vitro culture and selection

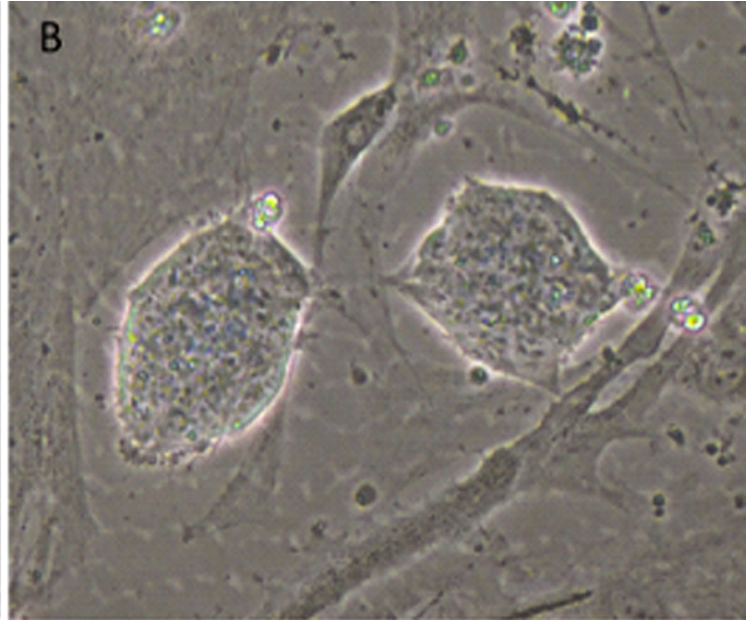

most promising, and may highly benefit from SCNT, leading not only to the improvement of herds aiming animal production, but also enabling the production recombinant proteins, reducing costs on pharmaceutical and biomedical fields.

Herein we discussed the transgenic technology, when associated to SCNT, and most recently, to cellular induced reprogramming. It is possible that together these strategies may allow the production of entire genetically modified herds in the future. 

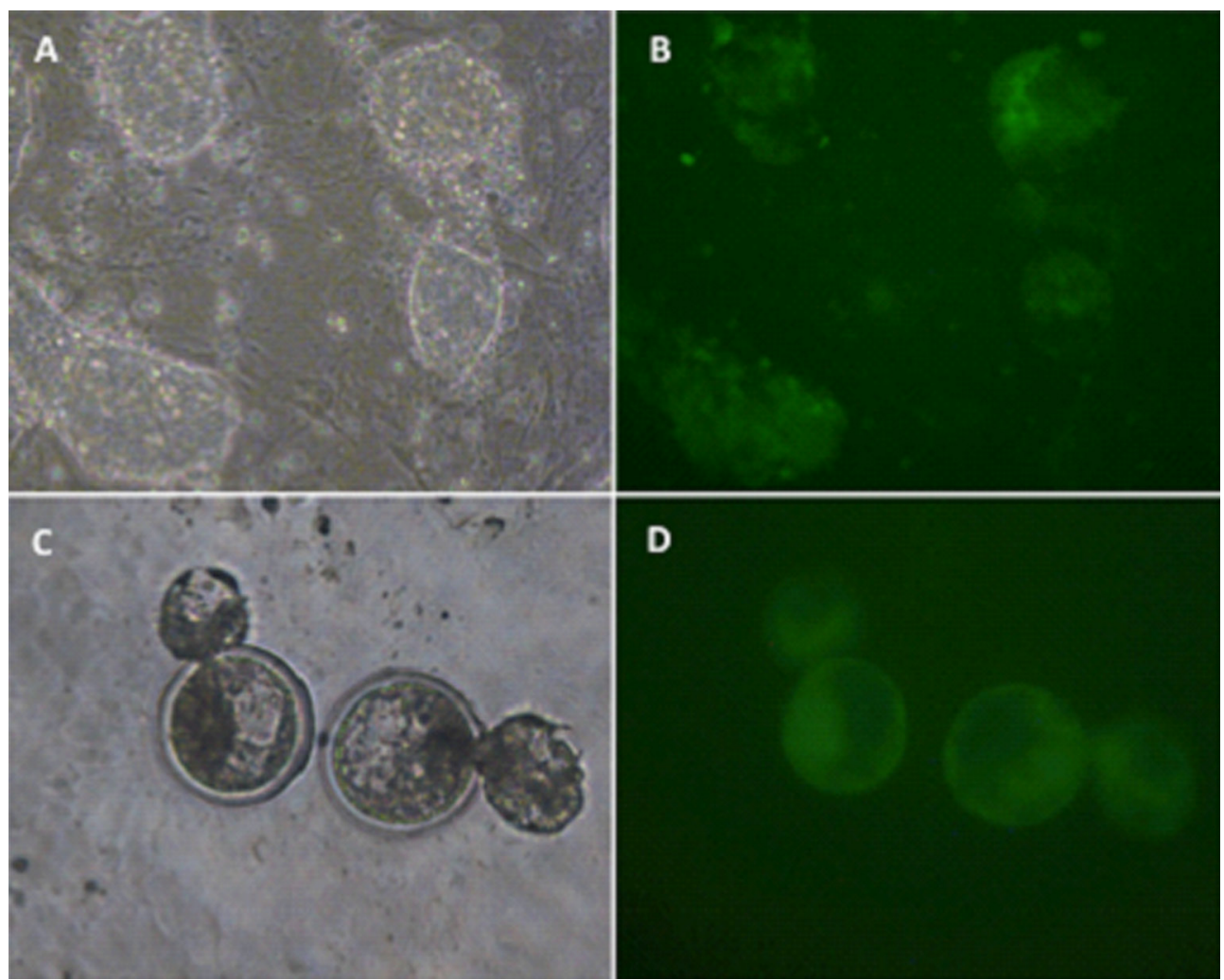

Fig.4. (A,B) biPS cells used as nuclei donor exposed to white light and fluorescence, respectively. 100x. (C,D) Cloned embryos reconstructed from biPS-eGFP cells exposed to light microscopy and fluorescence, respectively. 100x.

Induced pluripotent stem cells, when used in the SCNT technique, may result in new perspectives for the study and development of transgenic animals, once these cells may be more easily reprogrammed when compared to differentiated somatic cells and allow for long periods of cell culture.

Acknowledgements.- Authors would like to acknowledge the financial support from the National Institute of Science and Technology in Stem Cells and Cellular Therapy (Instituto Nacional de Ciência e Tecnologia em Células-tronco e Terapia Celular - INCTC, CNPq 573754/2008-0 and FAPESP 2008/57877-3), FAPESP processes 2009/11631-6, 2011/08376-4, 2008/00102-0, 2005/52676-1, 2011/51126-9, 2011/52018-5, Clonest Biotecnologia Animal, as well as the scientific support from Drs. Paulo Fantinato-Neto, Felipe Perecin, Paulo Sérgio Monzani and Flávia Verechia Thomaz Pereira.

\section{REFERENCES}

Bressan F.F., Dos Santos Miranda M., Perecin F., De Bem T.H., Pereira F.T., Russo-Carbolante E.M., Alves D., Strauss B., Bajgelman M., Krieger J.E., Binelli M. \& Meirelles F.V. 2011. Improved production of genetically modified fetuses with homogeneous transgene expression after transgene integration site analysis and recloning in cattle. Cell Reprogram. 13(1):29-36.

Cibelli J. 2007. Development: is therapeutic cloning dead? Science 318(5858):1879-1880.

Dean W., Santos F., Stojkovic M., Zakhartchenko V., Walter J., Wolfe E. \& Reik W. 2001. Conservation of methylation reprogramming in mammalian development: aberrant reprogramming in cloned embryos. Proc. Natl Acad. Sci. USA 98(24):13734-13738.

Esteban M.A., Xu J., Yang J., Peng M., Qin D., Li W., Jiang Z., Chen J., Deng K., Zhong M., Cai J., Lai L. \& Pei D. 2009. Generation of induced pluripotent stem cell lines from Tibetan miniature pig. J. Biol. Chem. 284(26):17634640.
Gordon J.W. \& Ruddle F.H. 1981. Integration and stable germ line transmission of genes injected into mouse pronuclei. Science 214:1244-1246.

Gossler A., Doetschman T., Korn R., Serfling E. \& Kemler R. 1986. Transgenesis by means of blastocyst-derived embryonic stem cell lines. Proc. Natl Acad. Sci. USA 83:9065-9069.

Hammer R.E., Pursel V.G., Rexroad Jr C.E., Wall R.J., Bolt D.J., Ebert K.M., Palmiter R.D. \& Brinster R.L. 1985. Production of transgenic rabbits, sheep and pigs by microinjection. Nature 315:680-683.

Hiiragi T. \& Solter D. 2005. Reprogramming is essential in nuclear transfer. Molec. Reprod. Develop. 70(4):417-421.

Hofmann A., Kessler B., Ewerling S., Weppert M., Vogg B., Ludwig H., Stojkovic M., Boelhauve M., Brem G., Wolf E. \& Pfeifer A. 2003. Efficient transgenesis in farm animals by lentiviral vectors. EMBO Rept 4:10541060.

Hofmann A., Zakhartchenko V., Weppert M., Sebald H., Wenigerkind H., Brem G., Wolf E. \& Pfeifer A. 2004. Generation of transgenic cattle by lentiviral gene transfer into oocytes. Biol. Reprod. 71:405-409.

Houdebine L.M. 2005. Use of transgenic animals to improve human health and animal production. Reprod. Domest. Anim. 40:269-281.

Jaenisch R. 1988. Transgenic animals. Science 240:1468-1474.

Keefer C.L., Pant D., Blomberg L. \& Talbot N.C. 2007. Challenges and prospects for the establishment of embryonic stem cell lines of domesticated ungulates. Anim. Reprod. Sci. 98:147-168.

Misra R.P. \& Duncan S.A. 2002. Gene targeting in the mouse: advances in introduction of transgenes into the genome by homologous recombination. Endocrine 19:229-238.

Meirelles F.V., Birgel E.H., Perecin F., Bertolini M., Traldi A.S., Pimentel J.R., Komninou E.R., Sangalli J.R., Neto P.F., Nunes M.T., Pogliani F.C., Meirelles F.D., Kubrusly F.S., Vannucchi C.I. \& Silva L.C. 2010. Delivery of cloned offspring: experience in Zebu cattle (Bos indicus). Reprod Fertil Dev. 22(1):88-97.

Monzani P.S., Bressan F.F., Mesquita L.G., Sangalli J.R. \& Meirelles F.V. 2011. $\beta$-casein gene expression by in vitro cultured bovine mammary epithe- 
lial cells derived from developing mammary glands. Genet. Mol. Res. 10(2):604-614.

Monzani P.S., Sangalli J.R., De Bem T.H., Bressan F.F., Fantinato-Neto P., Pimentel J.R., Birgel-Junior E.H., Fontes A.M., Covas D.T. \& Meirelles F.V. 2013. Breeding of transgenic cattle for human coagulation factor IX by a combination of lentiviral system and cloning. Genet. Mol. Res. 28:12.

Nagy K., Sung H.K., Zhang P., Laflamme S., Vincent P., Agha-Mohammadi S., Woltjen K., Monetti C., Michael I.P., Smith L.C. \& Nagy A. 2011. Induced pluripotentstemcell lines derived from equine fibroblasts. Stem Cell Rev. 7(3):693-702.

Park F. 2007. Lentiviral vectors: are they the future of animal transgenesis? Physiol. Genomics 31:159-173.

Pereira F.T.V., Oliveira L.J., Barreto R.S.N., Mess A.M., Perecin F., Bressan F.F., Mesquita L.G., Miglino M.A., Pimentel J.R.V., Fantinato-Neto P. \&
Meirelles F.V. 2013. Fetal-maternal interactions in the synepitheliochorial placenta using the eGFP cloned cattle model. Plos One 8(5): e64399.

Prelle K., Zakhartchenko V. \& Wolf E. 2002. Application of stem cell technology and nuclear transfer in animal models. Z. Ärztl. Fortbild. Qualitätssich. 96:434-440.

Sumer H., Liu J., Malaver-Ortega L.F., Lim M.L., Khodadadi K. \& Verma P.J.J. 2011. NANOG is a key factor for induction of pluripotency in bovine adult fibroblasts. J. Ani. Sci. 89(9):2708-716.

Wilmut I. 2002. Cloning and stem cells. Cloning Stem Cells 4(2):103-104.

Wongsrikeao P., Sutou S., Kunishi M., Dong Y.J., Bai X. \& Otoi T. 2011. Combination of the somatic cell nuclear transfer method and RNAi technology for the production of a prion gene-knockdown calf using plasmid vectors harboring the U6 or tRNA promoter. Prion 5(1):39-46. 